substantiation of which he directed his investigations, especially his redeterminations of atomic weights. $\mathrm{He}$ was elected an honorary and foreign fellow of the Chemical Society soon after the Great War, and the Society's Brauner Memorial Lecture was delivered by Dr. S. I. Levy on November 14. Dr. Levy has himself contributed to our knowledge of the rare earth elements and he was able to give a very lucid account of the way in which these very similar and difficultly separable bodies were isolated and identified as pure substances. Brauner's share in this work was very great, and is all the more noteworthy since it was very largely performed in adverse circumstances, for it was not until 1903 that the chemical institute of the Charles University of Prague was erected, largely as a result of Brauner's insistent pleas.

From his exhaustive researches, which led, among other things, to the fractionation. of didymium into praseodymium, neodymium and samarium, Brauner came to the conclusion that the rare earth elements from lanthanum to lutecium should be placed together in the Periodic Table. Brauner's other contributions to chemistry include his work upon the compounds of cerium and tellurium, concerning the homogeneity of which he was for a long while doubtful. It is interesting to note that some of his atomic weight determinations, even those of forty years ago, remain the accepted standards even to-day. It has perhaps never been generally realised how great his contributions were to the fundamentals of inorganic chemistry. Few of Brauner's original British friends remain. They include Mr. W. Macnab, who came to move the vote of thanks to Dr. Levy, and who recalled how Brauner's fine physique and unconventional, friendly manner always attracted admiration. Reference was made by Dr. G. Druce in seconding the vote of thanks to Brauner's interest in the transcription of Russian names into English, concerning which he had written several times in NATURE, and to the rapid progress in scientific research in many fields at Czechoslovak universities, largely as a result of Brauner's inspiring influence and example.

\section{Anatomy Department of St. Thomas's Hospital}

IMPORTANT alterations and additions to the Anatomy Department of St. Thomas's Hospital Medical School, London, have just been completed, and an "At Home" was held in the Department on November 14 when it was visited by representatives of the universities and of various London hospitals. Three new research laboratories and a large radiological laboratory, together with a director's room and an office, are housed in the new block. The dissecting-room has been completely renovated, and a new terrazzo floor has been laid. The museum has been equipped with special lighting arrangements for the exhibition of lantern-slides, X-ray negatives, bottled specimens and models. The $\mathrm{X}$-ray equipment is of the latest pattern, and is completely shockproof, and will serve not only for the instruction of students in all normal radiological appearances but also for research. An optical bench for photomicrography and for the reduction of $\mathrm{X}$-ray negatives has also been accommodated in the radiological laboratory, adjacent to which is a dark-room. The research laboratories are situated in the upper floor of the new block. They are magnificently lighted, and are furnished throughout with the most modern fittings. The visitors were afforded an opportunity of seeing some of the results of experiments which are being carried out in the Department in the use of the cinematograph for the teaching of anatomy. A composite film comprised portions of films showing respectively a dissection of the forearm, some examples of muscle-nerve paralyses, the surface anatomy of normal shoulder movements and a dissection illustrating the mechanism of the knee-joint. This Department is admirably fitted for the teaching of anatomy by modern methods, with emphasis on the study of living anatomy.

\section{Sir James Walker and the University of Edinburgh}

To commemorate the services of Sir James Walker, professor of chemistry at the University of Edinburgh from 1908 until 1928, to chemistry in general and to the Chemistry Department of the University of Edinburgh in particular, it is proposed to establish a fund for a Walker Memorial Lecture to be delivered annually by an eminent chemist invited to Edinburgh by the Edinburgh University Chemical Society for that purpose. Sir James Walker, who died in May of this year, was the leading exponent of physical chemistry in Great Britain for nearly fifty years. During the Great War he did valuable work in the manufacture of high explosives, and the new chemical laboratories which he designed and fitted up at Edinburgh are among the foremost, both in equipment and in research activity, in Great Britain. The Chemical Society of the University of Edinburgh enjoys the distinction of being the oldest chemical society in the world, since it has recently been established that it existed as far back as 1785 under the sponsorship of Joseph Black. It is felt that a yearly meeting at which the student members of this body may have the opportunity of making direct contact with the researches of distinguished in. vestigators in chemistry from other universities will provide a most stimulating permanent memorial of the labours of Sir James Walker for the advancement of the science in Edinburgh and elsewhere. Former students of Sir James Walker and any others who may wish to assist in the project are invited to send contributions to Mr. J. E. Rocea, honorary secretary of the Edinburgh University Chemical Society, King's Buildings, West Mains Road, Edinburgh.

\section{Memorial to Viscount Grey of Fallodon}

Lord Armstrong, president of the Natural History Society of Northumberland, Durham and Newcastleupon-Tyne, has issued an appeal for subscriptions towards a permanent 'North Country' memorial to commemorate the life of Viscount Grey. It is proposed to place a tablet to the memory of the great statesman and bird-lover in the Hancock Museum and to found a trust fund, the income of which will be applied to the endowment of the Museum. This 